\title{
Growth and nutrition of cowpea (Vigna unguiculata) under water deficit as influenced by microbial inoculation via seed coating
}

\author{
Inês Rocha ${ }^{1}$ Ying Ma ${ }^{1}$ Miroslav Vosátka ${ }^{2}$ Helena Freitas ${ }^{1}$ Rui S. Oliveira ${ }^{1,3}$
}

\begin{abstract}
Drought can drastically reduce cowpea [Vigna unguiculata (L.) Walp.] biomass and grain yield. The application of plant growth- promoting rhizobacteria and arbuscular mycorrhizal fungi can confer resistance to plants and reduce the effects of environmental stresses, including drought. Seed coating is a technique which allows the application of minor amounts of microbial inocula. Main effects of the factors inoculation and water regime showed that: severe or moderate water deficit had a general negative impact on cowpea plants; total biomass production, seed weight and seed yield were enhanced in plants inoculated with P. putida; inoculation of $R$. irregularis significantly increased nitrogen $(\mathrm{N})$ and phosphorus $(\mathrm{P})$ shoot concentrations; and $R$. irregularis enhanced both chlorophyll $\mathrm{b}$ and carotenoids contents, particularly under severe water deficit. Plants inoculated with P. putida $+R$. irregularis had an increase in shoot P concentration of $85 \%$ and $57 \%$, under moderate and severe water deficit, respec-tively. Singly inoculated $P$. putida improved potassium shoot concentration by $25 \%$ under moderate water deficit. Overall, in terms of agricultural productivity the inoculation of P. putida under water deficit might be promising. Seed coating has the poten-tial to be used as a large-scale delivery system of beneficial microbial inoculants.
\end{abstract}

KEYWORDS

arbuscular mycorrhizal fungi, plant growth-promoting bacteria, seed inoculation

\footnotetext{
${ }^{1}$ Centre for Functional Ecology - Science for People \& the Planet, Department of Life Sciences, University of Coimbra, Coimbra, Portugal

${ }^{2}$ Institute of Botany, Academy of Sciences of the Czech Republic, Průhonice, Czech Republic

${ }^{3}$ Department of Environmental Health, Research Centre on Health and Environment, School of Health, Polytechnic Institute of Porto, Porto, Portugal

Funding information Fundação para a Ciência e a Tecnologia, Grant/Award Number: PTDC/AGRTEC/1140/2014, SFRH/BPD/85008/2012, SFRH/BPD/76028/2011 and SFRH/ BD/100484/2014; Fundo Social Europeu (FSE); Programa Operacional do Capital Humano (POCH); Portuguese national funds through Programa Operacional Competitividade e Internacionalização (POCI), Project 3599 - Promover a Produção Científica e Desenvolvimento Tecnológico e a Constituição de Redes Temáticas, Grant/ Award Number: 3599-PPCDT; Fundo Europeu de Desenvolvimento Regional (FEDER), Grant/Award Number: POCI-010145-FEDER-016801
}

\section{1 | INTRODUCTION}

The agriculture sector is facing a real challenge against climate change (Vurukonda, Vardharajula, Shrivastava, \& Skz, 2016). With the increase in heat waves, storms, droughts, floods or heavy precipitation, crop productivity and food security are being endangered (Hansen, Sato, \& Ruedy, 2012; Sundström et al., 2014). Among these climate change threats, drought is expected to dramatically hamper plant growth and development for more than $50 \%$ of the arable lands by 2050 , decreasing crop productivity worldwide (Kasim et al., 2013; Li et al., 2014). From moderate and short to extremely severe and prolonged periods, drought can disturb plant water potential and turgor and thus modify physiological and morphological traits of plants (Rahdari \& Hoseini, 2012). 
Some beneficial soil microorganisms can help plants overcome problems caused by abiotic stress (Bardi \& Malusà, 2012; Bhardwaj, Ansari, Sahoo, \& Tuteja, 2014; Egamberdieva \& Adesemoye, 2016; Vassilev et al., 2015). The exploitation of plant beneficial microbes, such as plant growth-promoting rhizobacteria (PGPR) and arbuscular mycorrhizal (AM) fungi for drought stress mitigation in plants, is gaining importance (Li et al., 2014; Nadeem, Ahmad, Zahir, Javaid, \& Ashraf, 2014; Vurukonda et al., 2016). Besides their contribution to nutrient acquisition and biocontrol, PGPR can also confer drought tolerance in plants by osmotic adjustment, antioxidant metabolisms and phytohormone modulation (Rubin, van Groenigen, \& Hungate, 2017; Vurukonda et al., 2016). AM fungal symbiosis can improve plant antioxidant activity, osmotic regulation, photosynthetic rates and pigments, root water absorption and transport and uptake of nutrients, especially phosphorus (P) (Li et al., 2014; Oliveira, Rocha, Ma, Vosátka, \& Freitas, 2016; Oliveira, Ma et al., 2016; Quiroga, Erice, Aroca, Chaumont, \& Ruiz-Lozano, 2017).

Grain legumes are important for a variety of reasons, since they are a significant and cheap source of protein, are able to fix $\mathrm{N}$ in agricultural ecosystems and can be used for industrial and medicinal purposes (Farooq et al., 2017). Cowpea [Vigna unguiculata (L.) Walp.] is an important seed crop legume for human consumption (seeds and pods) and for soil amendment and fertilisation (e.g. green manure and organic material) (Vurukonda et al., 2016). Plant biomass and grain yield of legumes can be seriously hampered by moderate to severe drought stress (Farooq et al., 2017). Inoculation with AM fungi and PGPR has been considered to be a promising strategy to increase plant drought tolerance (Bhardwaj et al., 2014; Dodd \& Ruiz-Lozano, 2012). Some studies presented the effects of beneficial microbes on plant under water stress, such as improved grain yield and protein content (Oliveira et al., 2017a,b) increment on nutrient (Ngakou et al., 2007) and water uptake and increased transpiration and photosynthesis rates (Virakornphanich, Masuhara, \& Adachi, 1994). Therefore, it is imperative to develop feasible strategies for application of these beneficial microbes in open agricultural fields using minor amounts of inoculum for precision agriculture. Seed coating is a process where exogenous materials are applied to the surface of the seed and can be used for delivering active ingredients, including beneficial microbes (Pedrini, Merritt, Stevens, \& Dixon, 2017). This technique intends to use minor amounts of inocula in a more precise application that should be as efficiently as conventional soil inoculation. Seed coating could serve as a powerful tool for large-scale inoculation of beneficial microorganisms (Oliveira, Rocha et al., 2016).

The main goal of the present study was to assess the impact of the application of PGPR and AM fungi via seed coating in cowpea production under drought stress.

\section{MATERIALS AND METHODS}

\subsection{Seeds and soil material}

Seeds of cowpea [Vigna unguiculata (L.) Walp.] cv. Fradel were used in this study. The soil used in the experiment presented a loam texture with $\mathrm{pH}(1: 2.5 \mathrm{w} / \mathrm{v}$ water) 7.1, electrical conductivity $0.045 \mathrm{dS} / \mathrm{m}$, $0.16 \%$ organic matter, $0.11 \mathrm{~g} / \mathrm{kg}$ total $\mathrm{N}, 3,542 \mathrm{mg} / \mathrm{kg}$ extractable (Egner-Riehm) $\mathrm{P}$ and $13 \mathrm{mg} / \mathrm{kg}$ potassium (K). Previous to use the soil was sieved through a $4-\mathrm{mm}$ mesh and autoclaved twice $\left(121^{\circ} \mathrm{C}\right.$ for $25 \mathrm{~min}$ ) on consecutive days.

\section{2 | Microbial inocula and seed coating}

The AM fungus used was Rhizophagus irregularis $\mathrm{PH} 5$ grown for 8 months in a multispore pot culture containing a 1:1 (v/v) mixture of zeolite and expanded clay with Zea mays L. as host plant. Regarding the seed coating procedure, the $R$. irregularis inoculum was sieved through a 500- $\mu \mathrm{m}$ mesh and mixed with starch/silicon dioxide mixture (coating material) in the proportion of 1:1 $(\mathrm{w} / \mathrm{w})$ (the inoculum-coating material mixture was provided by Symbiom Ltd., Czech Republic). Pseudomonas putida strain GP was isolated from an agricultural soil in central Portugal used to grow Lupinus albus L. and tested positively for indoleacetic acid (IAA) (Brick, Bostock, \& Silverstone, 1991), ammonia (Cappuccino \& Sherman, 1992) and siderophores production (Schwyn \& Neilands, 1987), phosphate solubilisation (Gaur, 1990), N fixation (Dobereiner, Marriel, \& Nery, 1976), biofilm formation in the presence of different salt concentrations, 0.5 to $2.5 \mathrm{M}$ (Christensen et al., 1985) and water stress tolerance (Ma, Rajkumar, Zhang, \& Freitas, 2016). For the seed coating with bacteria, P. putida was grown in LB media for $17 \mathrm{hr}$ at $28-30^{\circ} \mathrm{C}$ and $150 \mathrm{rpm}$, centrifuged at $3,500 \mathrm{rpm}$ for $15 \mathrm{~min}$ and re-suspended in ringer solution with $1 \%$ carboxymethylcellulose (as an adhesive agent). The bacterial suspension at a concentration of $10^{8}$ colony-forming unit (CFU)/ $\mathrm{ml}$ was mixed with the coating material $(1: 1 \mathrm{v} / \mathrm{w})$. Both AM fungus and bacterium were also coated together using the same procedure and proportions $(1: 1: 1 \mathrm{w} / \mathrm{v} / \mathrm{w})$ as aforesaid. For seeds coated with $R$. irregularis, the AM fungal propagules per seed estimated by most probable number were 21 (Porter, 1979). Cowpea seeds were coated by the pan coating method (Scott, Hill, \& Jessop, 1991) as described by Oliveira, Rocha et al. (2016). Noninoculated control seeds were coated only with the starch/silicon dioxide mixture.

\section{3 | Experimental design}

This study was conducted in a heated greenhouse (temperature ranging from 18 to $30^{\circ} \mathrm{C}$ ) with an average photoperiod of $12 \mathrm{hr}$ using pots of $2 \mathrm{~L}$ disposed in a fully randomised scheme. Each pot received 1 seed. The positions of the pots were periodically swapped to minimise differences caused by their location in the greenhouse. All pots received $50 \mathrm{ml}$ of microbial populations filtrate (Whatman No. 1 filter) from the original non-sterile soil as described by Oliveira, Castro, Dodd, and Vosátka (2006), in order to provide a common soil microbiota for all the treatments. The experimental design involved twelve treatments, resulting from the combination of four inoculation treatments via seed coating [non-inoculated controls (Control); plants inoculated with 
Rhizophagus irregularis PH5 (RIcoat); Pseudomonas putida (PPcoat) and a mix of R. irregularis + P. putida (MIXcoat)] and three water regimes [no water deficit, $80-75 \%$ of water holding capacity (D0); moderate water deficit, $60-55 \%$ of water holding capacity (D1); and severe water deficit, $30-25 \%$ of water holding capacity (D2)]. Each treatment had six replicates. During the first 3 weeks of plant growth, water was supplied daily to reach $80 \%$ of water holding capacity in all treatments. Volumetric soil moisture was measured with a ML2x ThetaProbe (AT Delta-T Devices Ltd, Cambridge, UK), where changes in the apparent dielectric constant of moist soil allowed measuring the volumetric soil moisture content (Roth, Malicki, \& Plagge, 1992; White, Knight, Zegelin, \& Topp, 1994). Before starting the experiment, measures were performed to match the water holding capacity of the soil with the volumetric soil moisture. The 100\%, $85-80 \%, 60-55 \%$ and $30-$ $25 \%$ of soil water holding capacity corresponded to $22,16,10-9$ and 6-5\% volumetric soil moisture, respectively. In order to control water deficit and maintain it at the desire level, the soil water content was measured daily with the ThetaProbe ML2 $x$ at the end of the afternoon (5:00-6:00 p.m.) and the amount of water lost was added to each pot. For fertilisation, each plant received $20 \mathrm{ml}$ of modified white mineral solution P2N3 (Gryndler, Vejsadová, \& Vančura, 1992) twice a week.

\section{4 | Gas exchange parameters}

The steady-state net photosynthesis $A\left(P_{n}\right)$, stomatal conductance (gs), intercellular $\mathrm{CO}_{2}$ concentration ( $\mathrm{Ci}$ ) and transpiration rate ( $\mathrm{Tr}$ ) were determined using a Li-6400 IRGA (LI-COR, Lincoln, NE, USA). A $300 \mu \mathrm{mol} / \mathrm{s}$ flow of non-contaminated air was provided to the leaves using a leaf chamber and mass flow controllers. The analysed leaves were exposed to a saturating photosynthetic photon flux density of $1000 \mu \mathrm{mol} \mathrm{m} \mathrm{s}^{-2}$, block leaf temperature of $25^{\circ} \mathrm{C}$ and with the relative humidity of the air within the apparatus ranging between 45 and 55\%. In all cases, only mature, fully expanded leaves were selected for measurements from four different plants of each experimental condition. The measurements for gas exchange were recorded between the late morning (9:00-11:00 a.m.) and early afternoon (1:00-3:00 p.m.). The instantaneous water use efficiency (WUE) $\left(\mu \mathrm{mol} \mathrm{CO} \mathrm{CO}_{2}\right.$ per $\mathrm{mmol}_{2} \mathrm{O}$ ) was calculated by dividing the values of steady-state net photosynthesis by the transpiration rate $\left(P_{n} / T r\right)$.

\section{5 | Chlorophylls and carotenoids content}

Fresh cowpea leaves (about $0.2 \mathrm{~g}$ ) were homogenised in chilled $\mathrm{N}, \mathrm{N}$-dimethylformamide and stored overnight in the dark at $4^{\circ} \mathrm{C}$ (Moran \& Porath, 1980). The absorptions were measured at 664, 647 and $461 \mathrm{~nm}$ using a HACH DR/4000U spectrophotometer (HACH Company, Loveland, CO, USA). Chlorophyll a and chlorophyll b were estimated using the equations of Inskeep and Bloom (1985) and carotenoids using the equation of Chamovitz, Sandmann, and Hirschberg (1993).

\section{6 | Biomass production, seed yield and nutrients acquisition}

At harvest, pods were separated and weighted to determine fresh weights. After recording the weight of pods, seeds were collected and weighted. Shoots and roots were dried for 2 days at $75^{\circ} \mathrm{C}$ to obtain dry weights. Seed yield was calculated by multiplying the number of pod per plant by the number of seeds per pod and the seed weight mean (Sinha, 1977). After drying, shoots were grinded and digested according to the European Standard EN 13805 (2014). A segmented flow analyser was used for total $\mathrm{N}$ evaluation (Skalar Inc. SanPlus, The Netherlands) and inductively coupled plasma optical emission spectrometry (ICP-OES; GBC Quantima, Australia) for total $P$ and $K$. The ICP-OES operating conditions were as follows: 1,000 W RF power-1,000 W, 15.0 L/min plasma gas flow rate, $1.2 \mathrm{~L} / \mathrm{min}$ auxiliary gas flow rate, $1.0 \mathrm{~L} / \mathrm{min}$ carrier gas flow rate, 50 scan/reading, 3 measurement replicates and dual detector.

\section{7 | Mycorrhizal development}

Mycorrhizal colonisation in the roots of cowpea was assessed by microscopic methods. The roots were carefully washed and stained as described in a modified Phillips and Hayman (1970) protocol (Oliveira, Vosátka, Dodd, \& Castro, 2005). The percentage of root length colonised (RLC) was evaluated by the grid-line intersect method (Giovannetti \& Mosse, 1980) under a stereomicroscope (Leica EZ4 HD, Germany).

\subsection{Statistical analysis}

Normality and homogeneity of variances were confirmed and data analysed by one-way and two-way analysis of variance (ANOVA) for each dependent variable versus the independent variables (inoculation and water regime). In some cases, transformation was performed before analysis, to normalise skewed distributions before ANOVA. This was the case of data of mycorrhizal colonisation $\left(x^{2}\right), N$ shoot concentration $(1 / x)$, stomatal conductance $\left(x^{1 / 3}\right)$, transpiration rate $(\sqrt{ } x)$, water use efficiency $(1 / x)$ and carotenoids leaf content $(\sqrt{ } x)$. The main effects of the factors inoculation (Control, PPcoat, Rlcoat and MIXcoat), water regime (D0, D1 and D2) and their interaction were analysed. When a significant $F$-value was obtained $(p<0.05)$, treatment means were compared using Duncan's multiple range test. All statistical analyses were performed with the SPSS 25.0.0 software package (IBM SPSS Statistics, USA).

\section{3 | RESULTS}

\section{1 | Plant growth, yield and nutrients concentration}

Seeds coated with $R$. irregularis inoculum (singly or mix) took approximately 7 days to final emergence from the soil, while those inoculated with bacteria and control took 4 days. Shoots, roots and total dry weights of cowpea were negatively affected by 
TABLE 1 Biomass production and seed yield of Vigna unguiculata (L.) Walp. under different inoculation treatments [non-inoculated (Control) Rhizophagus irregularis (RIcoat), Pseudomonas putida (PPcoat) and the mix R. irregularis + P. putida (MIXcoat)] and no water deficit (D0), moderate water deficit (D1) and severe water deficit (D2)

\begin{tabular}{|c|c|c|c|c|c|c|c|}
\hline Inoculation & Water regime & $\begin{array}{l}\text { Shoot dry } \\
\text { weight (g) }\end{array}$ & $\begin{array}{l}\text { Root dry } \\
\text { Weight (g) }\end{array}$ & $\begin{array}{l}\text { Total plant dry } \\
\text { weight (g) }\end{array}$ & Root/Shoot ratio & Seed weight (g) & Seed yield (g) \\
\hline \multirow[t]{2}{*}{ Control } & DO & $1.2 \pm 0.1 \mathrm{~cd}$ & $0.9 \pm 0.1 \mathrm{e}$ & $2.0 \pm 0.2 \mathrm{~g}$ & $0.8 \pm 0.0 a b c$ & $0.07 \pm 0.0 \mathrm{ab}$ & $0.4 \pm 0.1 \mathrm{a}$ \\
\hline & D2 & $0.4 \pm 0.0 \mathrm{a}$ & $0.3 \pm 0.1 \mathrm{abc}$ & $0.8 \pm 0.1 \mathrm{bc}$ & $0.8 \pm 0.1 b c$ & $0.08 \pm 0.0 a b$ & $0.2 \pm 0.1 \mathrm{a}$ \\
\hline \multirow[t]{2}{*}{ PPcoat } & DO & $1.3 \pm 0.1 \mathrm{~d}$ & $0.9 \pm 0.1 \mathrm{e}$ & $2.1 \pm 0.1 \mathrm{~g}$ & $0.7 \pm 0.0 \mathrm{ab}$ & $0.22 \pm 0.0 c$ & $1.0 \pm 0.2 c$ \\
\hline & D2 & $0.4 \pm 0.0 \mathrm{a}$ & $0.5 \pm 0.1 \mathrm{~cd}$ & $0.9 \pm 0.1 \mathrm{bcd}$ & $1.1 \pm 0.2 c$ & $0.12 \pm 0.0 a b c$ & $0.4 \pm 0.1 \mathrm{a}$ \\
\hline \multirow[t]{3}{*}{ RIcoat } & D0 & $1.1 \pm 0.1 \mathrm{c}$ & $0.4 \pm 0.0 \mathrm{bcd}$ & $1.5 \pm 0.1 \mathrm{f}$ & $0.4 \pm 0.0 \mathrm{a}$ & $0.06 \pm 0.0 a$ & $0.3 \pm 0.2 \mathrm{a}$ \\
\hline & D1 & $0.6 \pm 0.1 b$ & $0.2 \pm 0.0 \mathrm{ab}$ & $0.8 \pm 0.1 \mathrm{bc}$ & $0.4 \pm 0.1 \mathrm{ab}$ & $0.08 \pm 0.0 \mathrm{ab}$ & $0.4 \pm 0.1 \mathrm{a}$ \\
\hline & D2 & $0.3 \pm 0.1 \mathrm{a}$ & $0.1 \pm 0.0 \mathrm{a}$ & $0.4 \pm 0.1 \mathrm{a}$ & $0.6 \pm 0.2 a b$ & $0.07 \pm 0.0 \mathrm{ab}$ & $0.2 \pm 0.1 \mathrm{a}$ \\
\hline MIXcoat & DO & $1.0 \pm 0.0 \mathrm{c}$ & $0.4 \pm 0.1 \mathrm{bcd}$ & $1.4 \pm 0.1 \mathrm{ef}$ & $0.4 \pm 0.1 \mathrm{a}$ & $0.05 \pm 0.0 \mathrm{a}$ & $0.4 \pm 0.1 \mathrm{a}$ \\
\hline
\end{tabular}

Note. Means $( \pm 1 \mathrm{SE}$ ) followed by letters that indicate significant differences between treatments according to Duncan's multiple range test at $p<0.05$.

water regime, especially by severe water deficit (Tables 1 and 2). In general, the roots and total biomass were significantly affected by the inoculation treatments, positively by $P$. putida and negatively by $R$. irregularis (Table 2). There was no significant effect of inoculation on shoot dry weight under the different water regimes when compared with control (Table 1). Overall, PPcoat treatment had a significant enhancement effect in total plant dry weight, seed weight and seed yield of cowpea (Table 2). Under moderate water deficit, plants inoculated with P. putida presented a significant increase in seed yield (Table 1). Rlcoat treatments presented lower root biomass when compared with the PPcoat and control treatments and consequently inferior values of root biomass over shoot (Table 2). The seed yield was significantly impaired by the severe water deficit (Table 2). Inoculation and water regime had significant main effects on cowpea shoot nutrients concentration (Table 2). In general, the presence of $R$. irregularis increased $\mathrm{N}$ and $\mathrm{P}$ shoot concentrations when compared with control (Table 2). Yet, the interaction between water regime and inoculation showed only significant increase of $\mathrm{N}$ in plants under no water deficit (Figure 1), with an increase of $38 \%$ in shoot concentration. Comparing with the corresponding control, P shoot concentration was significantly increased in the treatments of RIcoat D0, Mix D1

TAB LE 2 Main effects of the factors inoculation and water regime and two-way ANOVA F-values and significances for biomass production, seed yield and nutrient shoot concentration of Vigna unguiculata (L.) Walp

\begin{tabular}{|c|c|c|c|c|c|c|c|c|c|c|}
\hline \multicolumn{2}{|l|}{ Main Effects } & $\begin{array}{c}\text { Shoot dry } \\
\text { weight (g) } \\
0.7 \mathrm{ab}\end{array}$ & $\begin{array}{l}\text { Root dry } \\
\text { Weight (g) } \\
0.6 \mathrm{~b}\end{array}$ & $\begin{array}{l}\text { Total plant } \\
\text { dry weight } \\
\text { (g) } \\
1.3 \mathrm{~b}\end{array}$ & $\begin{array}{l}\text { Root/ } \\
\text { Shoot } \\
\text { ratio } \\
0.8 \mathrm{~b}\end{array}$ & $\begin{array}{l}\text { Seed } \\
\text { weight (g) } \\
0.1 \mathrm{a}\end{array}$ & $\begin{array}{l}\text { Seed } \\
\text { yield (g) } \\
0.4 \mathrm{a}\end{array}$ & $\begin{array}{l}\mathrm{N}\left(\mathrm{g} \mathrm{kg}^{-1}\right) \\
12.3 \mathrm{~b}\end{array}$ & $\begin{array}{c}\mathrm{P}\left(\mathrm{g} \mathrm{kg}^{-1}\right) \\
1.5 \mathrm{a}\end{array}$ & $\begin{array}{l}\mathrm{K}\left(\mathrm{g} \mathrm{kg}^{-1}\right) \\
25.3 \mathrm{a}\end{array}$ \\
\hline & PPcoat & $0.8 \mathrm{~b}$ & $0.6 \mathrm{~b}$ & $1.5 c$ & $0.9 \mathrm{~b}$ & $0.2 \mathrm{~b}$ & $0.7 \mathrm{~b}$ & $9.3 \mathrm{a}$ & $1.4 \mathrm{a}$ & $27.3 \mathrm{a}$ \\
\hline & Rlcoat & $0.7 \mathrm{a}$ & $0.3 \mathrm{a}$ & 0.9 a & $0.5 \mathrm{a}$ & $0.1 \mathrm{a}$ & $0.3 \mathrm{a}$ & $14.7 c$ & $2.0 \mathrm{~b}$ & $26.1 \mathrm{a}$ \\
\hline \multirow{2}{*}{$\begin{array}{l}\text { Water regime } \\
\text { (WR) }\end{array}$} & D1 & 0.7 y & 0.4 y & $1.2 \mathrm{y}$ & $0.6 x$ & $0.1 x$ & $0.6 y$ & $12.5 x$ & $1.6 x$ & $27.0 y$ \\
\hline & D2 & $0.4 x$ & $0.3 x$ & $0.7 x$ & $0.8 \mathrm{y}$ & $0.1 x$ & $0.2 x$ & $13.1 x$ & $1.8 x$ & $30.6 z$ \\
\hline \multicolumn{11}{|c|}{ Two-way ANOVA F-values and significances } \\
\hline \multicolumn{2}{|c|}{ Inoculation (I) } & $3.8^{*}$ & $19.9^{* * *}$ & $16.0^{* * *}$ & $8.3^{* * *}$ & $8.0^{* * *}$ & $9.2^{* * *}$ & $17.9^{* * *}$ & $15.0^{* * *}$ & $3.3^{*}$ \\
\hline
\end{tabular}

Notes. Letters indicate significant differences according to Duncan's Multiple Range test. ${ }^{* * *, * * *}$ significant effect at the level of $p<0.05, p<0.01$ and $p<0.001$, respectively; ns, non-significant effect. Control, non-inoculated; PPcoat, Pseudomonas putida; RIcoat, Rhizophagus irregularis; MIXcoat, mix of $R$. irregularis and P. putida; D0, no water deficit; D1, moderate water deficit; D2, severe water deficit. 
25

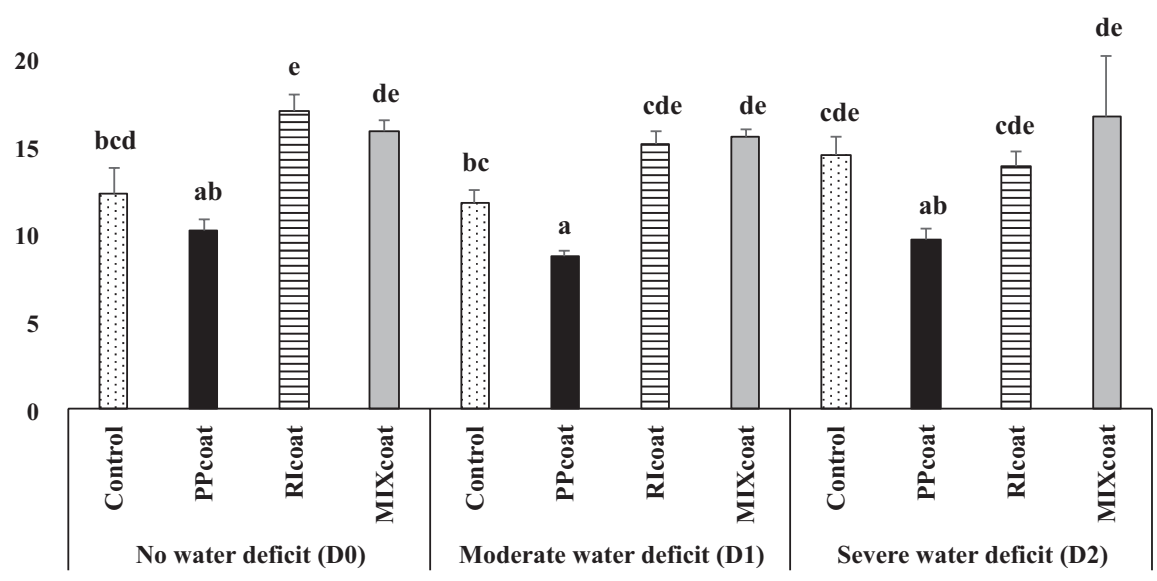

(b)

P (g/kg)

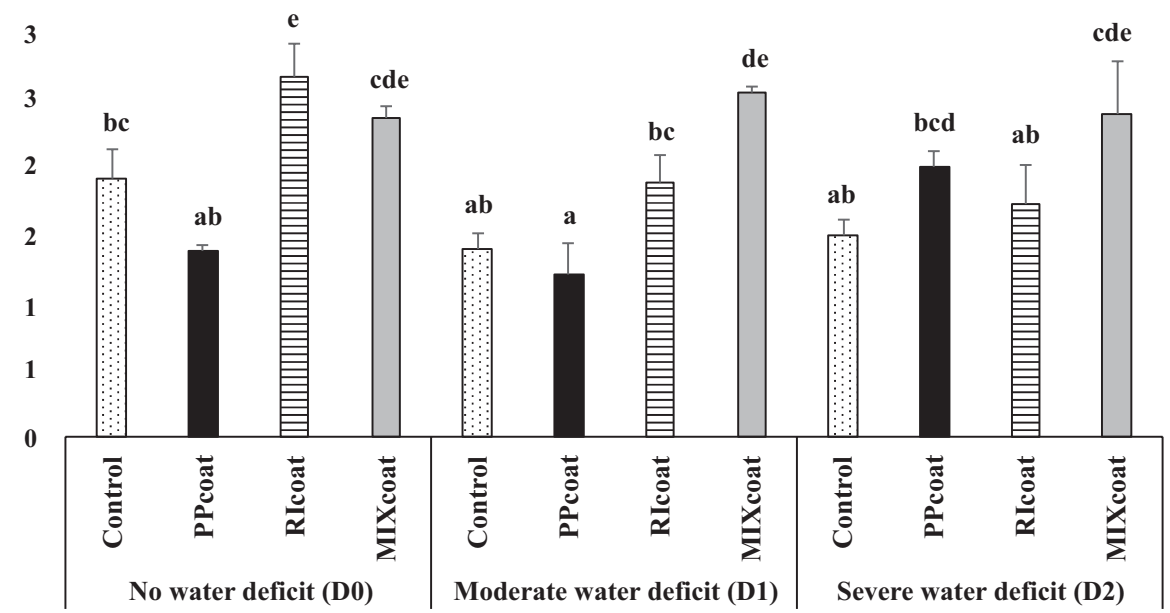

(c)

K (g/kg)

FIGURE 1 Effects of different inoculation treatments [non-inoculated (Control), with Rhizophagus irregularis (Rlcoat), Pseudomonas putida (PPcoat) and the mix R. irregularis + P. putida (MIXcoat)] and water regimes on $\mathrm{N}(\mathrm{a}), \mathrm{P}(\mathrm{b})$ and $\mathrm{K}(\mathrm{c})$ shoot concentration in Vigna unguiculata (L.) Walp. Values are means $\pm 1 S E$ and letters indicate significant differences $(p<0.05)$ according to Duncan's multiple range test

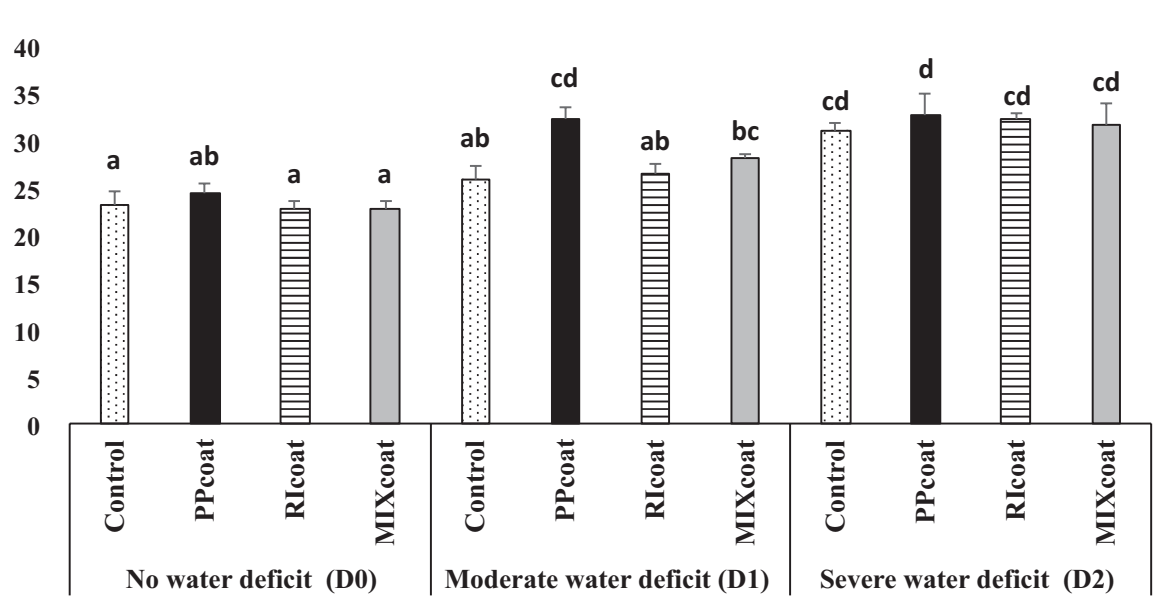

and $\mathrm{D} 2$ by $39 \%, 85 \%$ and $57 \%$, respectively. The accumulation of $\mathrm{K}$ in cowpea shoots was mainly affected by the water regime, being increased by moderate and severe water deficits (Table 2). Singly inoculated $P$. putida improved $\mathrm{K}$ shoot concentration by $25 \%$ under moderate water deficit (Figure 1).

\section{2 | Mycorrhizal root colonisation}

Plants without $R$. irregularis inoculation (control and P. putida inoculation) had no root mycorrhizal colonisation. Treatments where $R$. irregularis was inoculated had root colonisation that varied with water 


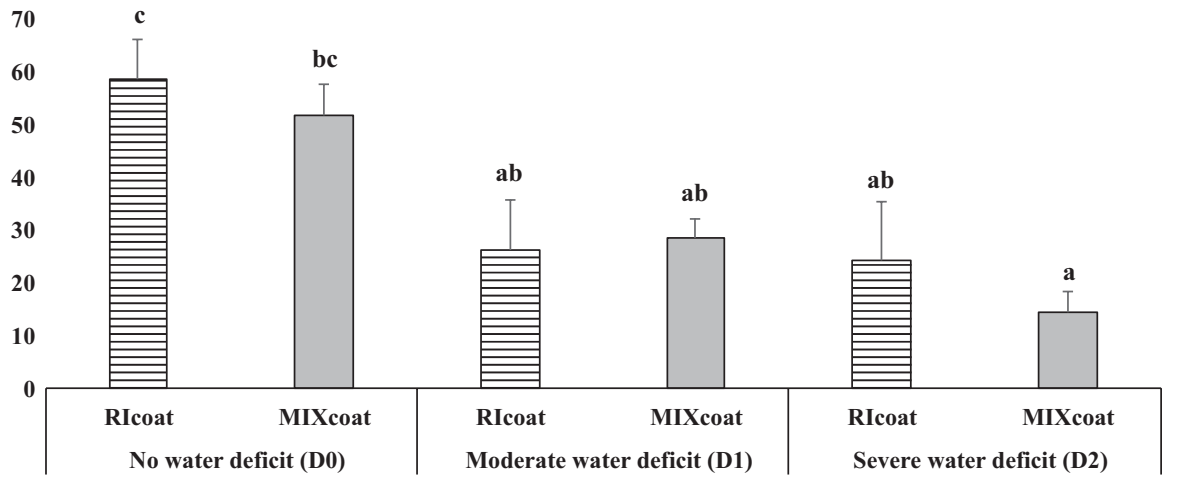

FIGURE 2 Percentage of root length colonisation (\% RLC) in the roots of Vigna unguiculata (L.) Walp. inoculated with Rhizophagus irregularis (RIcoat) or the mix R. irregularis + Pseudomonas Putida (MIXcoat) via seed coating under different water regimes. Values are means $\pm 1 \mathrm{SE}$ and letters indicate significant differences $(p<0.05)$ according to Duncan's multiple range test regime (Figure 2). Both moderated and severe water restrictions negatively affected the presence of $R$. irregularis in the roots. When no water deficit was imposed, the percentage of RLC was higher than $50 \%$. Inoculation with P. putida did not have a significant impact on root colonisation by $R$. irregularis.

\section{3 | Leaf parameters}

Both water regime and microbial inoculation influenced cowpea leaf gas exchange parameters (Figure 3a-e and Table 3). Severe water deficit negatively affected the gas exchange parameters in both non-inoculated and inoculated treatments (Figure 3 and Table 3). The presence of mycorrhiza singly and in combination with P. putida significantly enhanced $P_{n}$ when no water deficit was imposed (Figure 3a). Also, under no water deficit, the treatment MIXcoat presented higher values of gs and $\operatorname{Tr}$ (Figure $3 \mathrm{~b}$,d). Intercellular $\mathrm{CO}_{2}$ concentration was adversely impacted by severe water deficit (Table 3 ). Plants singly inoculated with $P$. putida showed the lower values of $P_{n}$, gs and $T r$ in all water regimes. WUE (Figure 3e) was significantly higher in plants under severe water deficit and in the presence of microbial inoculants.

Chlorophyll and carotenoids varied according to microbial inoculation and water regime (Figure 4 and Table 3). Plants under moderate and severe water deficit had significantly lower concentrations the leaf pigments, irrespective of microbial inoculation (Table 3). In general, plants inoculated with $R$. irregularis enhanced both chlorophylls and carotenoids contents, even under severe water deficit, when compared with PPcoat and control treatments (Table 3).

\section{4 | DISCUSSION}

The frequency and intensity of drought can dramatically decrease plant biomass and grain yield (Farooq et al., 2017). Ahmed and Suliman (2010) showed cowpea yield reductions of 34-66\% under water stress during the reproductive stage of crop development, and Akyeampong (1985) revealed $29 \%$ of declination during pod filling. Our results showed that both moderate and severe water deficit decreased shoots, roots and total biomass and that severe water deficit significantly reduced seed yield (Table 2 ). The negative variation on gas exchange parameters such as photosynthesis, stomatal conductance or transpiration imposed by water stress can hamper plant growth (Farooq et al., 2008; Li et al., 2014), which was shown in our results (Table 1 and Figure 3). Equally, water deficit significantly decreased the content of chlorophyll a, chlorophyll b and carotenoids in cowpea leaves (Table 3). Photosynthetic pigments are important for plants to harvest light and produce reducing powers. Carotenoids play a key role in plant antioxidant defence system by quenching singlet oxygen and peroxyl radicals, protecting the photosynthetic tissue from oxidative damage (Jaleel et al., 2009).

Legume crops are able to establish symbiotic interactions with microbes (e.g. PGPR and AM fungi), which help them cope with unfavourable environmental conditions such as drought (Oliveira et al., 2017a,b; Zahran, 2010).

Cowpea is considered to be highly mycotrophic (Molla \& Solaiman, 2009) which leads to enhancement of below and above ground biomass, nutrients accumulation, protein content and grain yield under different water regimes (Kwapata \& Hall, 1985; Oliveira et al., 2017a; Oruru, Njeru, Pasquet, \& Runo, 2018; Rabie, Aboul-Nasr, \& AlHumiany, 2005). However, our results showed that association between AM fungi and cowpea did not result in increased plant growth or seed yield (Tables 1 and 2). Moreover, for root weight and root/ shoot ratio the values of plants inoculated with $R$. irregularis were lower than control. This can be related to the fact that the production of fungal mycelium is much more cost-effective in terms of organic carbon (C) than the production of equivalent root length (Table 2). Consequently, plants adjust belowground $\mathrm{C}$ allocation contributing to the formation of a shorter mycorrhizal root system (Jacobsen, Smith, \& Smith, 2002), relying on the fungal mycelium for nutrient uptake (Smith, 2000). In fact, there was a significant enhancement in shoot nutrient content (Table 2), particularly $\mathrm{N}$ and $\mathrm{P}$, which has also been described in other studies with inoculated cowpea (Boby, Balakrishna, \& Bagyaraj, 2008; Oruru et al., 2018; Sanginga, Lyasse, \& Singh, 2000; Yaseen, Burni, \& Hussain, 2011). Still, this enhancement in nutrient content was not enough to result in greater yields, fact perhaps associated with the sink of carbohydrates of the fungal mycelium that the plant could not allocate to seed development and filling. Also, the observed delay on seedling emergence of plants inoculated with AM fungi might have a negative influence on cowpea yield or even adaptation to the water deficit. Faster germination 
(a) Photosynthetic rate $\mathrm{A}\left(\mathrm{P}_{\mathrm{n}}\right)$ $\mu \mathrm{mol} \mathrm{CO} \mathrm{Cm}^{-2} \mathrm{~s}^{-1}$

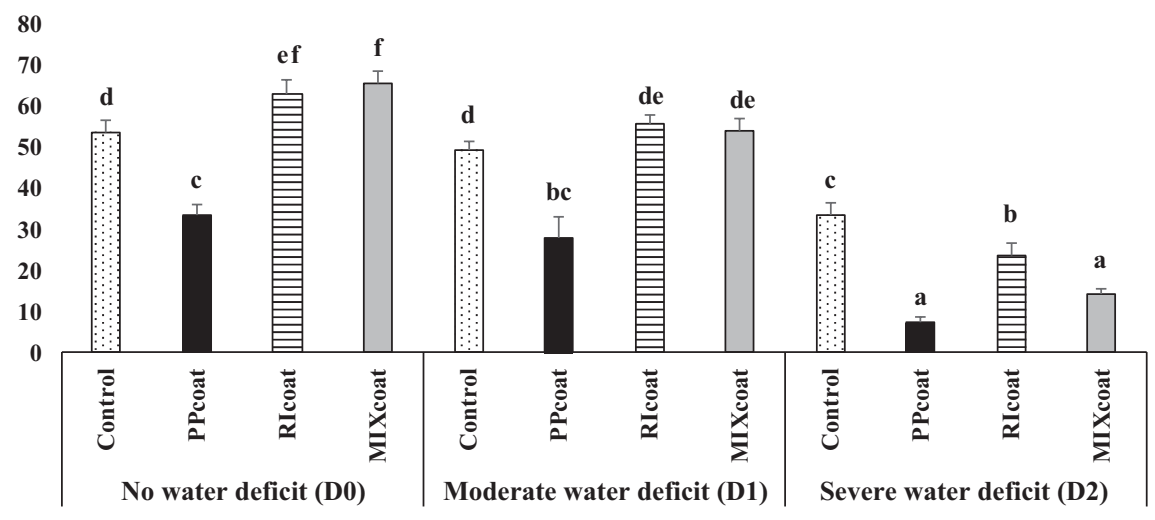

Stomatal conductance (gs)
$\mathrm{mol} \mathrm{H}_{2} \mathrm{O} \mathrm{m}^{-2} \mathrm{~s}^{-1}$

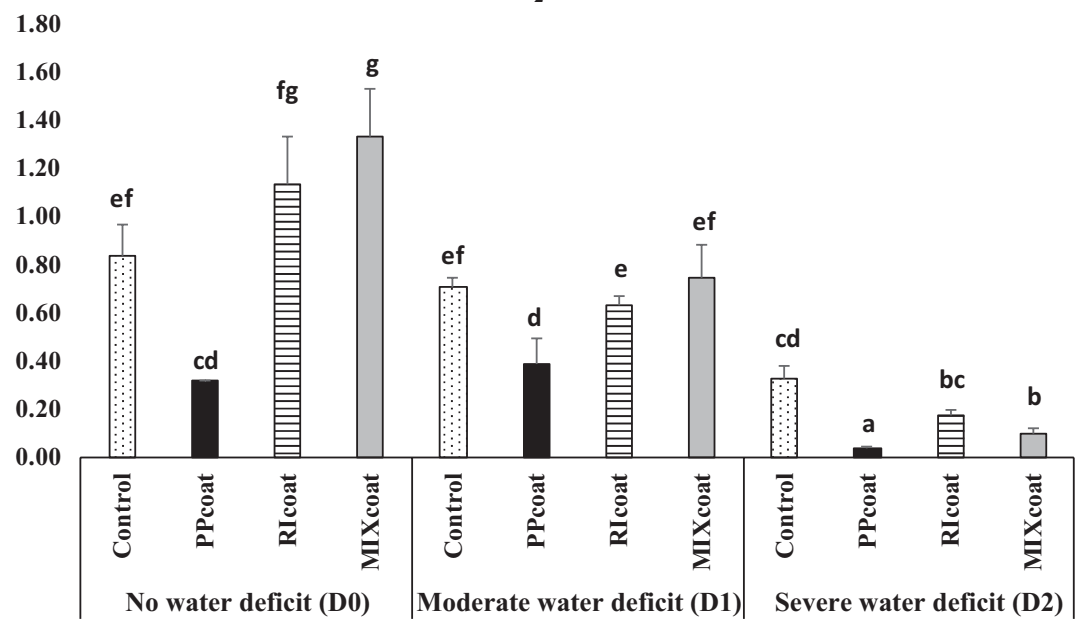

(c) Intercellular $\mathrm{CO}_{2}$ concentration $(\mathrm{Ci})$ $\mu \mathrm{mol} \mathrm{CO} / \mathrm{mol}$

FIGURE 3 Effects of microbial inoculation [non-inoculated (Control), Rhizophagus irregularis (RIcoat), Pseudomonas putida (PPcoat) and the mix of $R$. irregularis $+P$. putida (MIXcoat)] and water regime on $\mathrm{P}_{\mathrm{n}}(\mathrm{a})$, gs (b), $\mathrm{Ci}(\mathrm{c})$, $\mathrm{Tr}$, (d) and WUE (e) of Vigna unguiculata (L.) Walp. Letters indicate significant differences $(p<0.05)$ according to Duncan's multiple range test

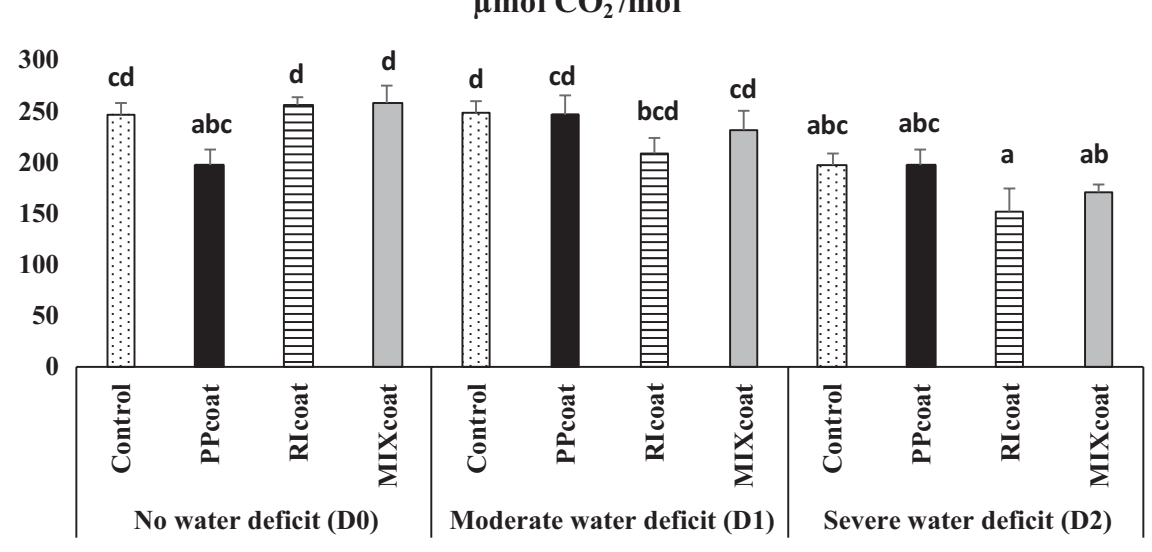

and establishment increases the opportunity of seedlings to achieve a positive $C$ and nutrient balance, which is crucial, especially under stress conditions (de Albuquerque \& de Carvalho, 2003). Further studies are, therefore, needed to improve this limitation on the germination of cowpea seeds coated with AM fungi.

On the other hand, when compared with control, there was an overall enhancement on chlorophyll and carotenoids contents in $R$. irregularis-inoculated plants (Table 3), particularly under severe water deficit for chlorophyll a and b (Figure 4). WUE, one of the mechanisms of plants to increase drought resistance (Vivas, Marulanda, Ruiz-Lozano, Barea, \& Azcón, 2003), was increased in plants inoculated with $R$. intraradices and $P$. putida under severe water deficit (Figure 3). The presence of mycorrhiza significantly enhanced photosynthetic rate, stomatal conductance and transpiration 

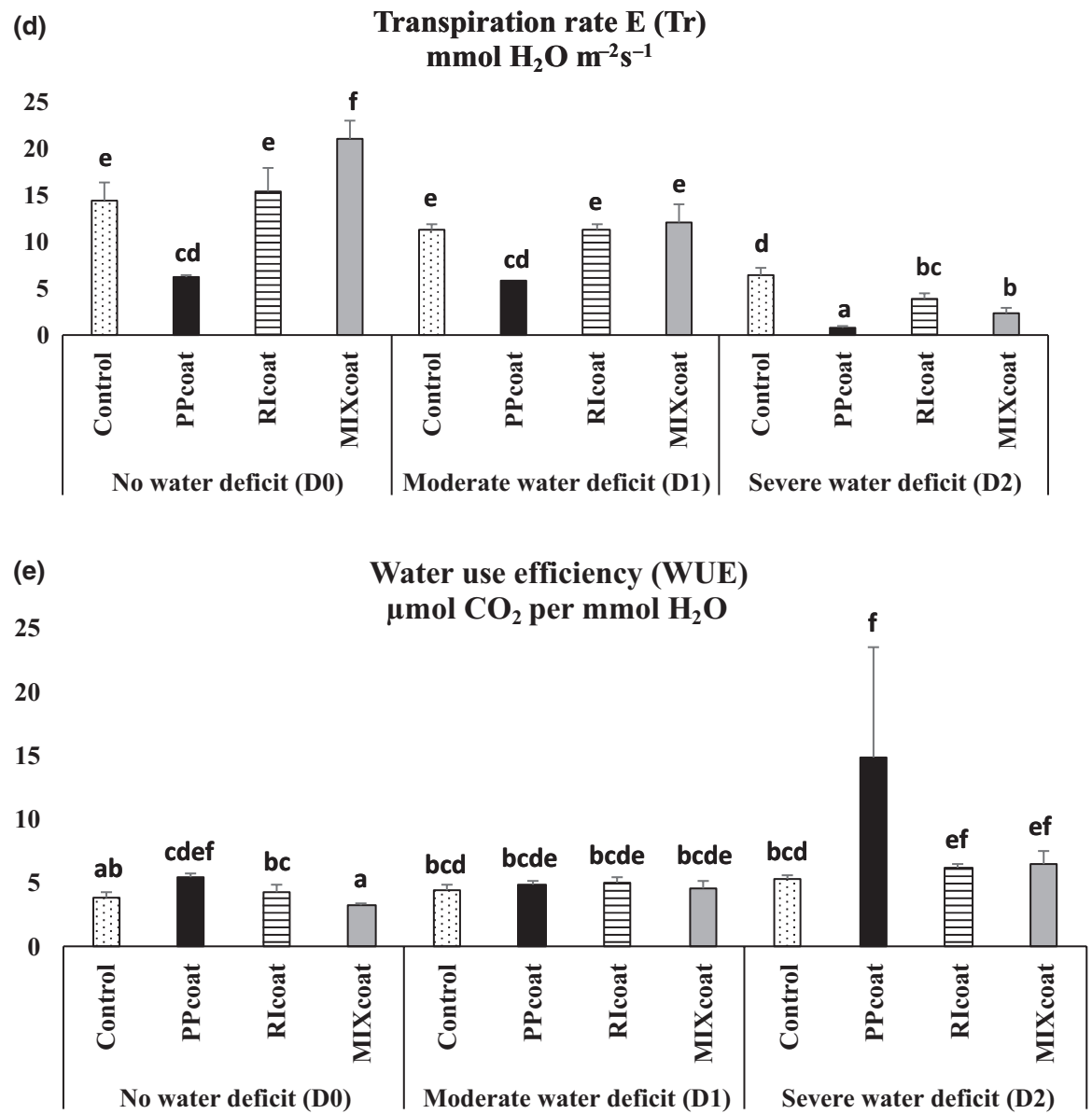

FIGURE 3 Continued

rate (Figure 3) under no water deficit, corresponding to the water regime where the colonisation was higher (Abdel-Salam, Alatar, \& El-Sheikh, 2017). The increased rate of photosynthesis was probably a result of the increased use of fixed C (Fitter, 1991) and/or higher chlorophyll content (Gusain, Singh, \& Sharma, 2015), under no water deficit (Figures 3 and 4). Under severe water deficit, this relationship between photosynthesis and chlorophyll content was not so obvious. Water deficit affects various physiological and biochemical processes of plants, limiting stomata and transpiration and resulting in reduced photosynthesis (Farooq, Wahid, Kobayashi, Fujita, \& Basra, 2009). These physiological limitations and decreased photosynthetic rate under water deficit possibly eliminated the compensatory effect of mycorrhiza shown in plants without water deficit. In fact, under water deficit the decrease in photosynthetic activity was also greater in mycorrhizal plants, as shown by Birhane, Sterck, Fetene, Bongers, and Kuyper (2012). Thus, this photosynthetic depression could have been responsible for the lower percentage of AM root colonisation. AM fungal colonisation is negatively influenced by water deficit (Kaya, Higgs, Kirnak, \& Tas, 2003; Oliveira et al., 2017a; Wu \& Xia, 2006), which, in the present study, might have been related to the observed reduction of cowpea fitness and to the lower production of photosynthates, meaningless $C$ for the fungal symbiont.

PGPR singly or in combination with AM fungi play a significant role in alleviating drought stress in plants (Vurukonda et al., 2016). In our results, the co-inoculation (PGPR + AM fungi) apparently did not present any extra benefit to the plants. On the other hand, plants singly inoculated with $P$. putida showed a significant increase in seed yield (Table 2), including under moderate water deficit (Table 1). Overall, P. putida significantly enhanced total plant biomass (Table 2). The accumulation of $\mathrm{K}$ in cowpea shoots was enhanced by $25 \%$ in plants singly inoculated with P. putida under moderate water deficit (Figure 1). $\mathrm{K}$ is an essential nutrient for plants and plays an important role in drought conditions, cell membrane stability, root growth and leaf area increase, water uptake and water conservation improvement (Wang, Zheng, Shen, \& Guo, 2013). The enhancement of K under moderate water deficit might be one of the factors responsible for improving cowpea tolerance to the stress and positively influencing seed yield, when comparing to the reaming treatments under the same water regime. The ability of PGPR to increase plant biomass, yield and protein content both under greenhouse and field conditions was shown before in legumes (Oliveira et al., 2017a,b; Sindhu, Dua, Verma, \& Khandelwal, 2010). Many studies with various crops showed a positive relationship between PGPR inoculation and drought tolerance (Figueiredo, Burity, Martínez, \& Chanway, 2008; Gusain et al., 2015; Kohler, Hernández, Caravaca, \& Roldán, 2008; Naseem \& Bano, 2014). In these studies, the production of phytohormones and the production of exopolysaccharides helped with drought stress alleviation and/or 


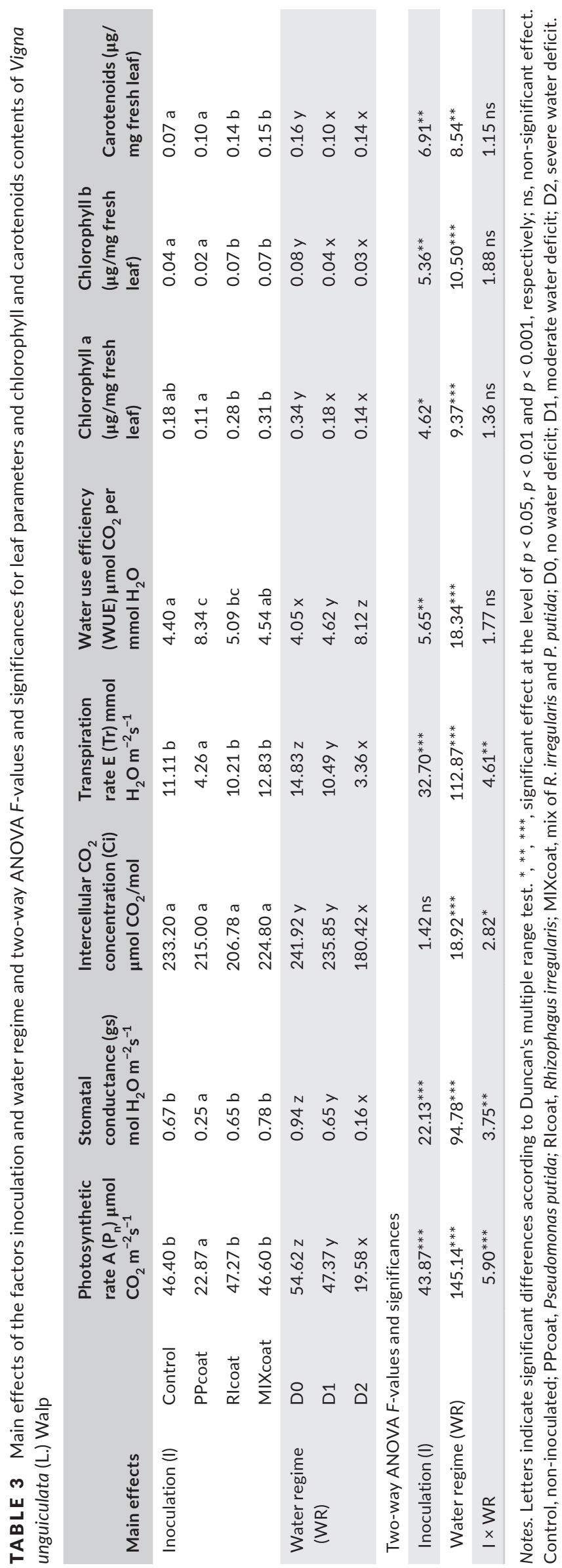

increased seed yield and protein content. The increase of drought stress tolerance by PGPR can be related to several mechanisms, such as production of phytohormones (abscisic acid, gibberellic acid, cytokinins and IAA); ACC deaminase; induced systemic tolerance; and production of exopolysaccharides (Vurukonda et al., 2016). The $P$. putida strain used in the present study is a strong IAA producer, which is physiologically the most active auxin in plant growth and development. Various plant species inoculated with IAA producing bacteria increased root growth thus increasing water and nutrient uptake and tolerance to water deficit (Vurukonda et al., 2016). More studies on the microbial mechanisms behind the increase in drought stress tolerance and yield are essential.

\section{5 | CONCLUSIONS}

It is imperative to improve agricultural productivity, in a sustainable way, against unfavourable environmental conditions. Understanding plant responses to drought is of great importance, since this is one of the main constraints to crop yield. Microbial inoculation is known to confer drought resistance to plants. In this study, results showed a general positive effect of bacterial inoculation via seed coating on crop productivity under moderated water deficit, which might be relevant for agricultural applications. AM fungal inoculation via seed coating had an overall positive influence on cowpea regarding the uptake of nutrients, leaf pigments content and gas exchange parameters, nonetheless mostly obtained under no water deficit. The application of PGPR and AM fungi represents a key approach for agricultural systems and should be integrated with or without drought stress, yet more studies concerning the microbe-plant interaction and the mechanisms that confer the stress alleviating abilities are necessary. Selecting the microbe that better potentiates plant tolerance is critical for the efficiency of microbial inoculation. On the other hand, seed coating can be a promising tool for efficiently delivering microbial inocula. Nonetheless, additional studies are needed to address the cowpea seed germination reduction and improve the technique. Moreover, field studies under real agricultural context are indispensable to prove the possible application of seed coating with PGPR and AM fungi in a large-scale approach. 


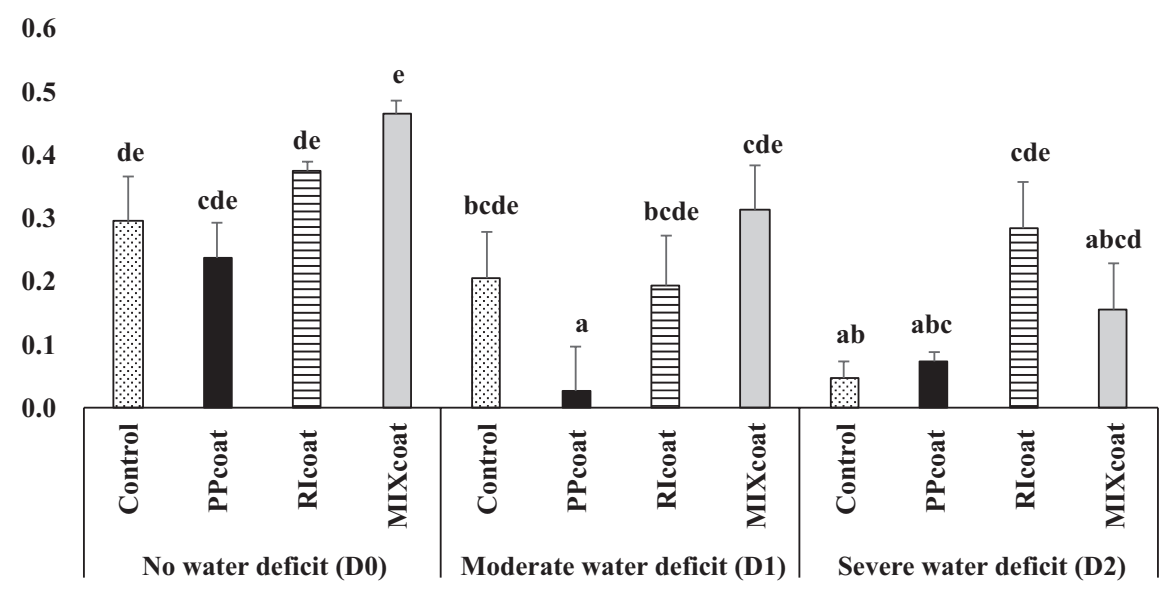
(b)

\section{Chlorophyllb ( $\mu \mathrm{g} / \mathrm{mg}$ fresh leaf)}

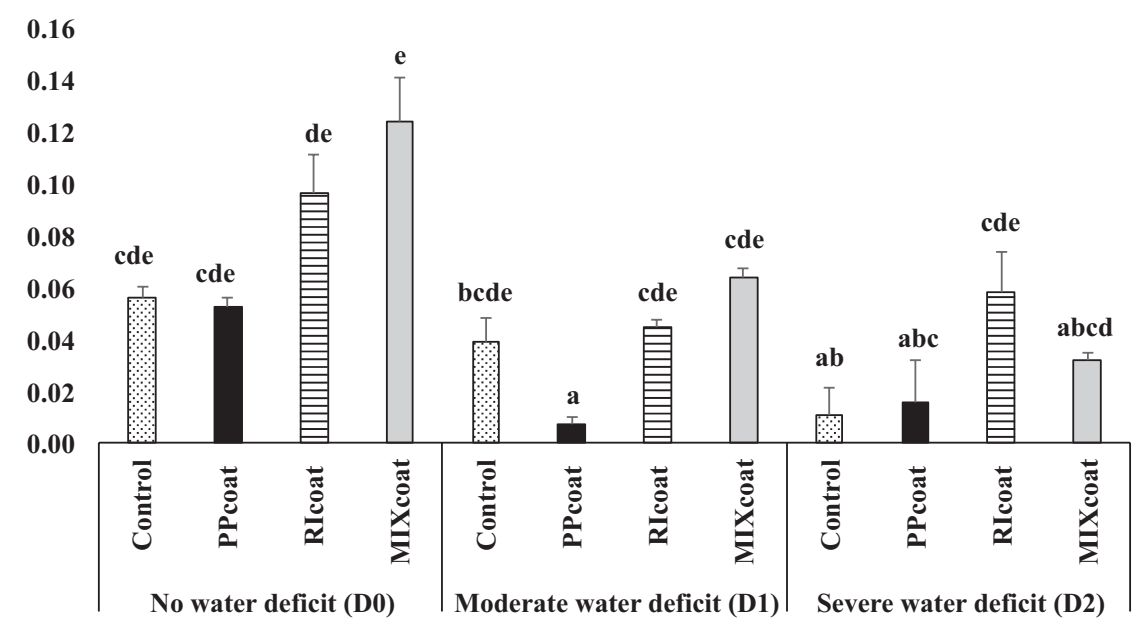

(c)

\section{Carotenoids $(\mu \mathrm{g} / \mathrm{mg}$ fresh leaf)}

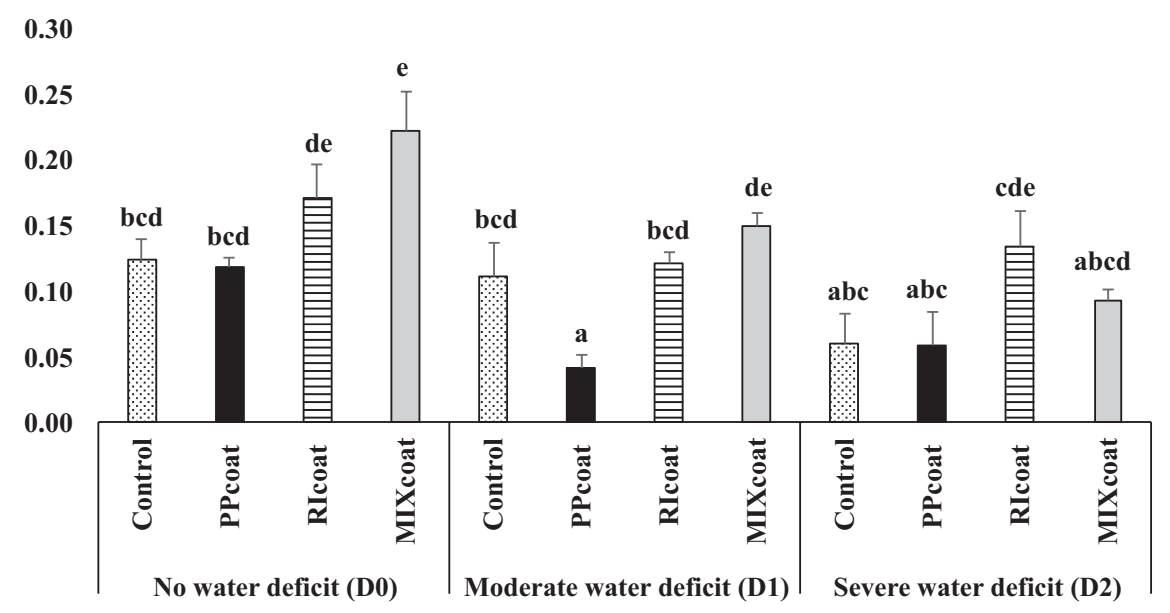

F I G UR E 4 Chlorophyll a (a), chlorophyll b, (b) and carotenoids (c) leaf concentrations of Vigna unguiculata (L.) Walp. under different inoculation treatments [non-inoculated controls (Control) and inoculated with Rhizophagus irregularis (RIcoat), Pseudomonas putida (PPcoat) and the mix of R. irregularis + P. putida (MIXcoat)] and water regimes. Letters indicate significant differences $(p<0.05)$ according to Duncan's multiple range test 


\section{REFERENCES}

Abdel-Salam, E., Alatar, A., \& El-Sheikh, M. A. (2017). Inoculation with arbuscular mycorrhizal fungi alleviates harmful effects of drought stress on damask rose. Saudi Journal of Biological Sciences. in press. https://doi.org/10.1016/j.sjbs.2017.10.015

Ahmed, F. E., \& Suliman, A. S. H. (2010). Effect of water stress applied at different stages of growth on seed yield and water-use efficiency of cowpea. Agriculture and Biology Journal of North America, 1, 534-540.

Akyeampong, E. (1985). Some responses of cowpea to drought stress. In Potentials of Forage Legumes in Farming Systems of Sub-Saharan Africa: Proceedings of a Workshop Held at ILCA, Addis Ababa, Ethiopia, 16-19 September 1985, p. 141. ILRI (aka ILCA and ILRAD).

de Albuquerque, F. M. C., \& de Carvalho, N. M. (2003). Effect of type of environmental stress on the emergence of sunflower (Helianthus annuus L.), soyabean (Glycine max (L.) Merril) and maize (Zea mays L.) seeds with different levels of vigor. Seed Science and Technology, 31, 465-467.

Bardi, L., \& Malusà, E. (2012). Drought and nutritional stresses in plant: Alleviating role of rhizospheric microorganisms. In N. Haryana \& S. Punj (Eds.), Abiotic stress: New research (pp. 1-57). New York, NY: Nova Science Publishers Inc. https://doi.org/10.1016/j. micres.2015.12.003

Bhardwaj, D., Ansari, M. W., Sahoo, R. K., \& Tuteja, N. (2014). Biofertilizers function as key player in sustainable agriculture by improving soil fertility, plant tolerance and crop productivity. Microbial Cell Factories, 13, 66. https://doi.org/10.1186/1475-2859-13-66

Birhane, E., Sterck, F. J., Fetene, M., Bongers, F., \& Kuyper, T. W. (2012). Arbuscular mycorrhizal fungi enhance photosynthesis, water use efficiency, and growth of frankincense seedlings under pulsed water availability conditions. Oecologia, 169, 895-904. https://doi. org/10.1007/s00442-012-2258-3

Boby, V. U., Balakrishna, A. N., \& Bagyaraj, D. J. (2008). Interaction between Glomus mosseae and soil yeasts on growth and nutrition of cowpea. Microbiological Research, 163, 693-700. https://doi. org/10.1016/j.micres.2006.10.004

Brick, J. M., Bostock, R. M., \& Silverstone, S. E. (1991). Rapid in situ assay for indoleacetic acid production by bacteria immobilized on nitrocellulose membrane. Applied and Environmental Microbiology, 57, 535-538.

Cappuccino, J. C., \& Sherman, N. (1992). Negative staining. In J. C. Cappuccino \& N. Sherman (Eds.), Microbiology: A laboratory manual (3rd ed., pp. 125-179). Redwood City, CA: Benjamin/Cummings Publishing Co., Inc.

Chamovitz, D., Sandmann, G., \& Hirschberg, J. (1993). Molecular and biochemical characterization of herbicide-resistant mutants of $c y-$ anobacteria reveals that phytoene desaturation is a rate-limiting step in carotenoid biosynthesis. Journal of Biological Chemistry, 268, 17348-17353.

Christensen, G. D., Simpson, W. A., Younger, J. J., Baddour, L. M., Barrett, F. F., Melton, D. M., \& Beachey, E. H. (1985). Adherence of coagulase negative Staphylococci to plastic tissue culture plates: A quantitative model for the adherence of Staphylococci to medical devices. Journal of Clinical Microbiology, 22, 996-1006.

Dobereiner, J., Marriel, I. E., \& Nery, M. (1976). Ecological distribution of Spirillum lipoferum Beijerinck. Canadian Journal of Microbiology, 22, 1464-1473.

Dodd, I. C., \& Ruiz-Lozano, J. M. (2012). Microbial enhancement of crop resource use efficiency. Current Opinion in Biotechnology, 23, 236242. https://doi.org/10.1016/j.copbio.2011.09.005

Egamberdieva, D., \& Adesemoye, A. O. (2016). Improvement of crop protection and yield in hostile agroecological conditions with PGPRbased biofertilizer formulations. In N. Arora, S. Mehnaz, \& R. Balestrini (Eds.), Bioformulations: For sustainable agriculture (pp. 199-211). New Delhi, India: Springer. https://doi.org/10.1007/978-81-322-2779-3

EN 13805. (2014). Foodstuffs - Determination of trace elements - Pressure digestion. Brussels, Belgium: European Committee for Standardization.

Farooq, M., Basra, S. M. A., Wahid, A., Cheema, Z. A., Cheema, M. A., \& Khaliq, A. (2008). Physiological role of exogenously applied glycinebetaine in improving drought tolerance of fine grain aromatic rice (Oryza sativa L.). Journal of Agronomy and Crop Science, 194, 325-333. https://doi.org/10.1111/j.1439-037X.2008. 00323.x

Farooq, M., Gogoi, N., Barthakur, S., Baroowa, B., Bharadwaj, N., Alghamdi, S. S., \& Siddique, K. H. M. (2017). Drought stress in grain legumes during reproduction and grain filling. Journal of Agronomy and Crop Science, 203, 81-102. https://doi.org/10.1111/jac.12169

Farooq, M., Wahid, A., Kobayashi, N., Fujita, D., \& Basra, S. M. A. (2009). Plant drought stress: Effects, mechanisms and management. Agronomy for Sustainable Development, 29, 185-212. https://doi. org/10.1051/agro:2008021

Figueiredo, M. V., Burity, H. A., Martínez, C. R., \& Chanway, C. P. (2008). Alleviation of drought stress in the common bean (Phaseolus vulgaris L.) by co-inoculation with Paenibacillus polymyxa and Rhizobium tropici. Applied Soil Ecology, 40, 182-188. https://doi.org/10.1016/j. apsoil.2008.04.005

Fitter, A. H. (1991). Costs and benefits of mycorrhizas: Implications for functioning under natural conditions. Experientia, 47, 350-355. https://doi.org/10.1007/BF01972076

Gaur, A. C. (1990). Physiological functions of phosphate solubilizing micro-organisms. In A. C. Gaur (Ed.), Phosphate solubilizing micro-organisms as biofertilizers (pp. 16-72). New Delhi, India: Omega Scientific Publishers. https://doi.org/10.10007/978-3-319-08216-5

Giovannetti, M., \& Mosse, B. (1980). An evaluation of techniques for measuring vesicular arbuscular mycorrhizal infection in roots. New Phytologist, 84, 489-500. https://doi.org/10.1111/j.1469-8137. 1980.tb04556.x

Gryndler, M., Vejsadová, H., \& Vančura, V. (1992). The effect of magnesium-ions on the vesicular arbuscular mycorrhizal infection of maize roots. New Phytologist, 122, 455-460. https://doi. org/10.1111/j.1469-8137. 1992.tb00073.x

Gusain, Y. S., Singh, U. S., \& Sharma, A. K. (2015). Bacterial mediated amelioration of drought stress in drought tolerant and susceptible cultivars of rice (Oryza sativa L.). African Journal of Biotechnology, 14, 764-773. https://doi.org/10.5897/AJB2015.14405

Hansen, J., Sato, M., \& Ruedy, R. (2012). Perception of climate change. Proceedings of the National Academy of Sciences, 109, E2415-E2423. https://doi.org/10.1073/pnas.1205276109

Inskeep, W. P., \& Bloom, P. R. (1985). Extinction coefficients of chlorophyll a and b in N, N-dimethylformamide and $80 \%$ acetone. Plant Physiology, 77, 483-485. https://doi.org/10.1104/pp.77.2.483

Jacobsen, I., Smith, S. E., \& Smith, F. A. (2002). Function and diversity of arbuscular mycorrhizae in carbon and mineral nutrition. In M. G. A. van der Heijden \& I. R. Sanders (Eds.), Mycorrhizal ecology (1st ed., pp. 75-92). Berlin, Germany: Springer.

Jaleel, C. A., Manivannan, P., Wahid, A., Farooq, M., Somasundaram, R., \& Panneerselvam, R. (2009). Drought stress in plants: A review on morphological characteristics and pigments composition. International Journal of Agriculture and Biology, 11, 100-105.

Kasim, W. A., Osman, M. E., Omar, M. N., El-Daim, I. A. A., Bejai, S., \& Meijer, J. (2013). Control of drought stress in wheat using plantgrowth-promoting bacteria. Journal of Plant Growth Regulation, 32, 122-130. https://doi.org/10.1007/s00344-012-9283-7

Kaya, C., Higgs, D., Kirnak, H., \& Tas, I. (2003). Mycorrhizal colonization improves fruit yield and water use efficiency in watermelon (Citrullus lanatus Thunb) grown under well-watered and 
water-stressed conditions. Plant and Soil, 253, 287-292. https://doi. org/10.1023/A:1024843419670

Kohler, J., Hernández, J. A., Caravaca, F., \& Roldán, A. (2008). Plantgrowth-promoting rhizobacteria and arbuscular mycorrhizal fungi modify alleviation biochemical mechanisms in water-stressed plants. Functional Plant Biology, 35, 141-151. https://doi.org/10.1071/ FP07218

Kwapata, M. B., \& Hall, A. E. (1985). Effects of moisture regime and phosphorus on mycorrhizal infection, nutrient uptake, and growth of cowpeas (Vigna unguiculata (L.) Walp.). Field Crops Research, 12, 241-250. https://doi.org/10.1016/0378-4290(85)90072-3

Li, T., Lin, G., Zhang, X., Chen, Y., Zhang, S., \& Chen, B. (2014). Relative importance of an arbuscular mycorrhizal fungus (Rhizophagus intraradices) and root hairs in plant drought tolerance. Mycorrhiza, 24, 595-602. https://doi.org/10.1007/s00572-014-0578-3

Ma, Y., Rajkumar, M., Zhang, C., \& Freitas, H. (2016). Inoculation of Brassica oxyrrhina with plant growth promoting bacteria for the improvement of heavy metal phytoremediation under drought conditions. Journal of Hazardous Materials, 320, 36-44. https://doi. org/10.1016/j.jhazmat.2016.08.009

Molla, M. N., \& Solaiman, A. R. M. (2009). Association of arbuscular mycorrhizal fungi with leguminous crops grown in different agroecological zones of Bangladesh. Archives of Agronomy and Soil Science, 55, 233-245. https://doi.org/10.1080/03650340802477726

Moran, R., \& Porath, D. (1980). Chlorophyll determination in intact tissues using n,n-dimethylformamide. Plant physiology, 65, 478-479. https://doi.org/10.1104/pp.65.3.478

Nadeem, S. M., Ahmad, M., Zahir, Z. A., Javaid, A., \& Ashraf, M. (2014). The role of mycorrhizae and plant growth promoting rhizobacteria (PGPR) in improving crop productivity under stressful environments. Biotechnology Advances, 32, 429-448. https://doi.org/10.1016/j. biotechadv.2013.12.005

Naseem, H., \& Bano, A. (2014). Role of plant growth-promoting rhizobacteria and their exopolysaccharide in drought tolerance of maize. Journal of Plant Interactions, 9, 689-701. https://doi.org/10.1080/17 429145.2014.902125

Ngakou, A., Nwaga, D., Nebane, C. L. N., Ntonifor, N. N., Tamò, M., \& Parh, I. A. (2007). Arbuscular-mycorrhizal fungi, rhizobia and Metarhizium anisopliae enhance $\mathrm{P}, \mathrm{N}, \mathrm{Mg}, \mathrm{K}$, and $\mathrm{Ca}$ accumulations in fields grown cowpea. Journal of Plant Sciences, 2, 518-529. https:// doi.org/10.3923/jps.2007.518.529

Oliveira, R. S., Carvalho, P., Marques, G., Ferreira, L., Pereira, S., Nunes, M., ... Freitas, H. (2017a). Improved grain yield of cowpea (Vigna unguiculata) under water deficit after inoculation with Bradyrhizobium elkanii and Rhizophagus irregularis. Crop and Pasture Science, 68, 10521059. https://doi.org/10.1071/CP17087

Oliveira, R. S., Carvalho, P., Marques, G., Ferreira, L., Pereira, S., Nunes, M., ... Freitas, H. (2017b). Increased protein content of chickpea (Cicer arietinum L.) inoculated with arbuscular mycorrhizal fungi and nitrogen-fixing bacteria under water deficit conditions. Journal of the Science of Food and Agriculture, 97, 4379-4385. https://doi. org/10.1002/jsfa.8201

Oliveira, R. S., Castro, P. M., Dodd, J. C., \& Vosátka, M. (2006). Different native arbuscular mycorrhizal fungi influence the coexistence of two plant species in a highly alkaline anthropogenic sediment. Plant and Soil, 287, 209-221. https://doi.org/10.1007/s11104-006-9067-6

Oliveira, R. S., Ma, Y., Rocha, I., Carvalho, M. F., Vosátka, M., \& Freitas, $H$. (2016). Arbuscular mycorrhizal fungi are an alternative to the application of chemical fertilizer in the production of the medicinal and aromatic plant Coriandrum sativum L. Journal of Toxicology and Environmental Health, Part A, 79, 320-328. https://doi.org/10.1080/ 15287394.2016.1153447

Oliveira, R. S., Rocha, I., Ma, Y., Vosátka, M., \& Freitas, H. (2016). Seed coating with arbuscular mycorrhizal fungi as an ecotechnological approach for sustainable agricultural production of common wheat
(Triticum aestivum L.). Journal of Toxicology and Environmental Health, Part A, 79, 329-337. https://doi.org/10.1080/15287394.2016.1153 448

Oliveira, R. S., Vosátka, M., Dodd, J. C., \& Castro, P. M. (2005). Studies on the diversity of arbuscular mycorrhizal fungi and the efficacy of two native isolates in a highly alkaline anthropogenic sediment. Mycorrhiza, 16, 23-31. https://doi.org/10.1007/s00572-005-0010-0

Oruru, M. B., Njeru, E. M., Pasquet, R., \& Runo, S. (2018). Response of a wild-type and modern cowpea cultivars to arbuscular mycorrhizal inoculation in sterilized and non-sterilized soil. Journal of Plant Nutrition, 41, 90-101. https://doi.org/10.1080/01904167.2017.138 1728

Pedrini, S., Merritt, D. J., Stevens, J., \& Dixon, K. (2017). Seed coating: Science or marketing spin? Trends in Plant Science, 22, 106-116. https://doi.org/10.1016/j.tplants.2016.11.002

Phillips, J. M., \& Hayman, D. S. (1970). Improved procedures for clearing and staining parasitic and vesicular-arbuscular mycorrhizal fungi for rapid assessment of infection. Transactions of the British Mycological Society, 55, 158-161. https://doi.org/10.1016/ S0007-1536(70)80110-3

Porter, W. (1979). The "most probable number" method for enumerating infective propagules of vesicular arbuscular mycorrhizal fungi in soil. Australian Journal of Soil Research, 17, 515-519. https://doi. org/10.1071/SR9790515

Quiroga, G., Erice, G., Aroca, R., Chaumont, F., \& Ruiz-Lozano, J. M. (2017). Enhanced drought stress tolerance by the arbuscular mycorrhizal symbiosis in a drought-sensitive maize cultivar is related to a broader and differential regulation of host plant aquaporins than in a drought-tolerant cultivar. Frontiers in Plant Science, 8, 1056. https:// doi.org/10.3389/fpls.2017.01056

Rabie, G. H., Aboul-Nasr, M. B., \& Al-Humiany, A. (2005). Increased salinity tolerance of cowpea plants by dual inoculation of an arbuscular mycorrhizal fungus Glomus clarum and a nitrogen-fixer Azospirillum brasilense. Mycobiology, 33, 51-60. https://doi.org/10.4489/ MYCO.2005.33.1.051

Rahdari, P., \& Hoseini, S. M. (2012). Drought stress: A review. International Journal of Agronomy and Plant Production, 3, 443-446.

Roth, C. H., Malicki, M. A., \& Plagge, R. (1992). Empirical evaluation of the relationship between soil dielectric constant and volumetric water content as the basis for calibrating soil moisture measurements. European Journal of Soil Science, 43, 1-13. https://doi. org/10.1111/j.1365-2389.1992.tb00115.x

Rubin, R. L., van Groenigen, K. J., \& Hungate, B. A. (2017). Plant growth promoting rhizobacteria are more effective under drought: A metaanalysis. Plant and Soil, 416, 309-323. https://doi.org/10.1007/ s11104-017-3199-8

Sanginga, N., Lyasse, O., \& Singh, B. B. (2000). Phosphorus use efficiency and nitrogen balance of cowpea breeding lines in a low $\mathrm{P}$ soil of the derived savanna zone in West Africa. Plant and Soil, 220, 119. https:// doi.org/10.1023/A:1004785720047

Schwyn, B., \& Neilands, J. B. (1987). Universal chemical assay for the detection and determination of siderophores. Analytical Biochemistry, 160, 47-56. https://doi.org/10.1016/0003-2697(87)90612-9

Scott, J. M., Hill, C. B., \& Jessop, R. S. (1991). Growth chamber study of phosphorus applied as drilled granules or as seed coatings to wheat sown in soils differing in P-sorption capacity. Fertilizer Research, 29, 281-287. https://doi.org/10.1007/BF01052397

Sindhu, S. S., Dua, S., Verma, M. K., \& Khandelwal, A. (2010). Growth promotion of legumes by inoculation of rhizosphere bacteria. In M. S. Khan, J. Musarrat, \& A. Zaidi (Eds.), Microbes for legume improvement (pp. 195-235). Vienna, Austria: Springer. https://doi. org/10.1007/978-3-211-99753-6_9

Sinha, S. K. (1977). Yield, yield components and plant ideotype in food legumes. In Food Legume Crops: Improvement and Production. FAO Plant Production and Protection Serials, 9, 123-131. 
Smith, F. A. (2000). Measuring the influence of mycorrhizas. New Phytologist, 148, 4-6. https://doi.org/10.1111/j.1469-8137.2000. 00751_148_1.x

Sundström, J. F., Albihn, A., Boqvist, S., Ljungvall, K., Marstorp, H., Martiin, C., ... Magnusson, U. (2014). Future threats to agricultural food production posed by environmental degradation, climate change, and animal and plant diseases - A risk analysis in three economic and climate settings. Food Security, 6, 201-215. https://doi. org/10.1007/s12571-014-0331-y

Vassilev, N., Vassileva, M., Lopez, A., Martos, V., Reyes, A., Maksimovic, I., ... Malusà, E. (2015). Unexploited potential of some biotechnological techniques for biofertilizer production and formulation. Applied Microbiology and Biotechnology, 99, 4983-4996. https://doi. org/10.1007/s00253-015-6656-4

Virakornphanich, P., Masuhara, G., \& Adachi, K. (1994). Effect of arbuscular mycorrhizal inoculation on growth and phosphorus content of cowpea under water-stressed conditions. In Strategies for the Northeast Agricultural Development in the 21st Century, Khon Kaen (Thailand), (1994, October 20-21).

Vivas, A., Marulanda, A., Ruiz-Lozano, J. M., Barea, J. M., \& Azcón, R. (2003). Influence of a Bacillus sp. on physiological activities of two arbuscular mycorrhizal fungi and on plant responses to PEG-induced drought stress. Mycorrhiza, 13, 249-256. https://doi.org/10.1007/ s00572-003-0223-z

Vurukonda, S. S. K. P., Vardharajula, S., Shrivastava, M., \& Skz, A. (2016). Enhancement of drought stress tolerance in crops by plant growth promoting rhizobacteria. Microbiological Research, 184, 13-24. https://doi.org/10.1016/j.micres.2015.12.003

Wang, M., Zheng, Q., Shen, Q., \& Guo, S. (2013). The critical role of potassium in plant stress response. International Journal of Molecular Sciences, 14, 7370-7390. https://doi.org/10.3390/ijms14047370

White, I., Knight, J. H., Zegelin, S. J., \& Topp, G. C. (1994). Comments to 'Considerations on the use of time-domain reflectometry (TDR) for measuring soil water content' by W.R. Whalley. European Journal of Soil Science, 45, 503-508. https://doi.org/10.1111/j.1365-2389.1994. tb00536.x

Wu, Q. S., \& Xia, R. X. (2006). Arbuscular mycorrhizal fungi influence growth, osmotic adjustment and photosynthesis of citrus under well-watered and water stress conditions. Journal of Plant Physiology, 163, 417-425. https://doi.org/10.1016/j. jplph.2005.04.024

Yaseen, T., Burni, T., \& Hussain, F. (2011). Effect of arbuscular mycorrhizal inoculation on nutrient uptake, growth and productivity of cowpea (Vigna unguiculata) varieties. African Journal of Biotechnology, 10, 8593-8598. https://doi.org/10.5897/ AJB10.1494

Zahran, H. H. (2010). Legumes-microbes interactions under stressed environments. In M. S. Khan, J. Musarrat, \& A. Zaidi (Eds.), Microbes for legume improvement (pp. 353-387). Vienna, Austria: Springer. https:// doi.org/10.1007/978-3-211-99753-6_15 